\title{
PERSONALITY ADJUSTMENTS AS FACTORS AFFECTING ACADEMIC PERFORMANCE OF TERTIARY EDUCATION SUBSIDY (TES) GRANTEES
}

\author{
Helen C. Fuentes, Ph.D. \\ Assistant Professor, Eastern Samar State University, Eastern Samar, Philippines
}

Article DOI: https://doi.org/10.36713/epra8700

DOI No: $10.36713 /$ epra8700

\begin{abstract}
This is a correlation research describing the personality adjustments and academic performance of Tertiary Education Subsidy grantees. A total of 265 randomly TES grantees were the respondents for the study. Data were gathered through adapted questionnaires using online platforms. The null hypothesis was tested using the Spearman's Rank Correlation. The level of significance was set at .05 for rejecting or accepting the null hypothesis. Results of the study revealed the following: delaying gratification on food, physical pleasures, social interaction, money, and achievement were sometimes practiced by the grantees; giving importance to aspects of identity such as relational, social, and collective identities were frequently practiced while giving importance to personal identity was seen to be always practiced by the grantees; majority of the grantees exhibited satisfactory academic performance; the relationship between personality adjustments in terms of delayed gratification and academic performance was statistically not significant while identity orientation had significant relationship with the academic performance of the grantees.
\end{abstract}

KEYWORDS: TES Grantees, personality adjustments, academic performance, subsidy

\section{INTRODUCTION}

Education is one of the significant things man pursues. A good education affects several facets in life. Becoming a degree holder would mean better opportunities and a better life. The correlation between the family's socio-economic status and the student's school achievement or performance is widely established. The differences in the academic achievements of students belonging to varying socioeconomic classes are more or less unchanging for students aged 7-11 years (Grades 2-6), but broadens at an increasing rate for those aged 11-15 years. As the children from low-income households, grow older, their school performance worsens, which tends to increase the likelihood of leaving school (Temple, 2009).

The Tertiary Education Subsidy (TES) is the initiative of the Philippine government to provide poor but capable students with access to higher education. It intends to raise the quantity of advanced education graduates among financially disable families through direct arrangement of financing for their schooling. The TES, as one of the government's sort of Conditional Cash Transfer (CCT) program has huge implications to of grantees. Character changes may emerge during the progress time frame from
non-TES to TES grantee. As per Maranda et al. (2016) recipients of CCT like the ESGP-PA grantees dread that they would not arrive at their fantasies, while monetary troubles and financial components, obstructed them from arriving at their objectives. Subsequently, it is critical to look at the character parts of the TES grantees to illuminate strategy making body. Receiving such amount may challenge a grantees' ability to resist the temptation of spending for immediate rewards to fulfil his personal identity orientations.

Delaying gratification is the capacity to oppose the enticement of a quick award in inclination for a later prize. It was seen that delaying gratification was a significant center segment of effective character change (Maranda et al, 2016). Personal Identity can be viewed as an individual that has not one "personal self" but instead a few selves that correspond to widening circles of group membership. The idea of Self Identity is clarified through three (3) central mental instruments that underlie it, which include: social arrangement, social correlation, and positive peculiarity. Progress alludes to an entry from a day to day existence stage, condition or status to another which includes both cycle and result of complex individual-environment interaction. 
All together for TES beneficiaries to prevail in their examinations and complete their curricular programs, it is speculated that they ought to have an unmistakable perspective on the change that they go through as they are starting higher education degree, and it is vital that they acquire attention to the difficulties they face as they proceed with the TES program. Knowing their dreams and figuring their objectives would help them in the change from youthfulness to youthful adulthood. Also, they ought to have the option to postpone delight, to such an extent that it permits the beneficiaries to suspend satisfaction of quick needs and inclinations for a more noteworthy award which is a professional education. It is additionally estimated that beneficiaries who are in the juvenile time frame is currently fostering their characters and it is essential to decide if their self-personality understanding is related with their academic performance.

The findings of this study will contribute to the body of knowledge on personality adjustments on delay of gratification, and identity orientations and their influence to students' academic performance.

\section{Objectives of the Study}

This study aimed to determine the factors that affect the academic performance of TES grantees in Eastern Visayas. Specifically, it aimed to attain the following objectives:

1. to describe the personality adjustments of TES grantees in terms of the following:

1.1 delayed gratification, and

1.2 identity orientation;

2. to assess the academic performance of TES grantees; and

3. to establish if there is significant relationship between personality adjustments and academic performance of TES grantees in Eastern Samar State University.

\section{METHODS}

The current study used the quantitative correlational method with the questionnaire as the principal instrument to gather the necessary data. First, the data on TES grantees' delayed gratification, identity orientations, and the academic performance were described. After which, correlation of variables was performed to find out if there is significant relationship between personality adjustments (as categorized into delayed gratification and identity orientations) and academic performance of TES.

This study involved a total of 265 randomly selected TES grantees from Eastern Visayas, Philippines. Proportionate stratified random sampling technique was used and he total number of respondents was determined from the total number of population using the Krejcie and Morgan's Table for
Determining Sample Size of a Known Population (1970)

Two research instruments were used: (1) The Delay of Gratification Inventory (DGI), created and validated by Hoerger, was used to measure the respondents' personality adjustment in terms of delayed gratification. The DGI consists of 35 items which is composed of the five domains of delaying behavior, involving food, physical pleasures, social interactions, money, and achievement; and (2) Aspects of Identity Questionnaire-IV (AIQIV), this is a 45-item objective inventory that measures the importance of four aspects of identity orientations in individual's self-concepts: a) personal identity, or the importance of one's psychological traits and other personal attributes; b) relational identity, or how individuals see themselves in the contexts of their intimate relationships ; c) social identity, or how the individuals see themselves in more general interpersonal contexts; and d) collective identity, or how individuals represent their various reference group identities (Cheek, 2013).

The responses on personality adjustments were tallied scored and analyzed using descriptive and inferential statistics. In the scoring process, negatively stated indicators were reversely coded. Mean, frequencies, and percentage were used to tabulate, analyze, and interpret the data obtained from the instruments. The personality adjustments as categorized into delayed gratification and identity orientations were determined by computing the weighted mean. The academic performance of TES grantees on the basis of their General Weighted Average (GWA) was summarized using frequency and percentage. The hypothesis that stated there is significant relationship between personality adjustment and academic performance of TES grantees in Eastern Visayas, was tested using the Spearman's Rank Correlation. The level of significance is set at .05 for rejecting or accepting the null hypothesis. The University Research Ethics Committee approved this study (Approval Reference Number 009-21-GS).

\section{RESULTS AND DISCUSSION}

\section{Personality Adjustments of TES Grantees}

Delayed Gratification. Characteristics of the 265 TES grantees in terms of delayed gratification were presented in terms of the five (5) domains of delayed gratification namely: (1) food; (2) physical pleasures; (3) social; (4) money; and (5) achievement.

Food. The item "I have always tried to eat healthy because it pays off in the long run" got the highest mean rating of 4.12 which means frequently practiced while item "Sometimes I eat until I make myself sick" got the lowest mean rating of 2.14 which means rarely practiced. The overall mean of 3.18 means that TES grantees sometimes practiced 
delaying gratification in terms of food. The result implies that like the children in the Marshmallow Experiment who were willing to delay gratification ended up higher SAT scores, in the present study the grantees that practiced delaying gratification on food may have better academic performance as indicated by higher general weighted average.

Physical Pleasures. Based on the respondents' responses pertaining to the measure of delayed gratification in terms of physical pleasures, the item "I am able to control my physical desires" got the highest mean rating of 4.07 which means frequently practiced while the item "I prefer to explore the physical side of romantic involvements right away" got the lowest mean rating of 2.00 which means rarely practiced. The overall mean is 3.12 which mean delayed gratification on physical pleasure is sometimes practiced by the respondents.

The result implies that the grantees had the ability to resist temptation on physical pleasures and stick to their goals or for something better.

Social Interaction. Among the indicators, item "I think that helping each other benefits society" got the highest mean rating of 4.47 which means always practiced, while item "I do not consider how my behavior affects other people" got the lowest mean rating of 1.88 which means rarely practiced. The overall mean is 3.34 indicated the grantees sometimes practice delaying gratification for social interaction.

Money. In terms of money, the item "When I am able to, I try to save away a little money in case an emergency should arise" got the highest mean rating of 4.29 which means always practiced. While items "When someone gives me money, I prefer to spend it right away" and "It is hard for me to resist buying things I cannot afford" got a mean rating ranging from 1.00 to 1.79 which means never practiced. The overall mean of 2.86 which means sometimes practiced indicates that the grantees give value to money and tried to delay gratification in terms of money.

Achievement. The measure of delayed gratification in terms of achievement shows that items "I have tried to work hard in school so that I could have a better future" and "I worked hard in school to improve myself as a person" got the mean rating ranging from 4.20 to 5.00 which means always practiced, while items "I cannot motivate myself to accomplish long-term goals"; "I would rather take the easy road in life than get ahead" and "In school, I tried to take the easy way out" got a mean rating ranging from 1.80 to 2.59 which means rarely practiced. The overall mean of 3.29 is interpreted as sometimes practiced. This result indicates that the TES grantees are working hard in order to achieve their goals in life.

Table 1 presents the summary of the personality adjustment of the 265 TES grantees in terms of delayed gratification. As shown, all indicators got an overall mean rating ranging from 2.60 to 3.39 which mean sometimes practiced. The grand mean of 3.16 is interpreted as sometimes practiced as well. Further examination on the mean ratings revealed that TES grantees had the ability to adjust and resist short term gratification in favor of the long term one especially in terms of achievement. This result is similar to the findings of Maranda et al. (2016) when they measured the level of delayed gratification among ESGPPA Grantees who were also 4Ps members. This result implies that the grantees sometimes in many areas their life choose a long-term reward over immediate gratification. Hence, they perhaps believe that the ability to delay gratification can mean the difference between achieving their goals or not.

Table 1. Summary on personality adjustments of TES grantees in terms of delayed gratification

\begin{tabular}{|c|c|c|}
\hline Indicators & Mean & Interpretation \\
\hline Food & 3.18 & Sometimes Practiced \\
\hline Physical Pleasures & 3.12 & Sometimes Practiced \\
\hline Social Interaction & 3.34 & Sometimes Practiced \\
\hline Money & 2.86 & Sometimes Practiced \\
\hline Achievement & 3.29 & Sometimes Practiced \\
\hline Grand Mean & 3.16 & Sometimes Practiced \\
\hline
\end{tabular}

\section{Identity Orientation}

Personal Identity. Based on the respondents' responses pertaining to their identity orientation, items "I give importance to my personal goals and hopes for the future"; "I give importance to my personal values and moral standards"; "I give importance to my self-knowledge, my ideas about what kind of person I really am"; and "I give importance to my personal self-evaluation, the private opinion I have of myself" got a mean rating ranging from 4.20 to 5.00 which means always practiced while other indicators for personal identity got a mean ranging from 3.40 to 4.19 which fall under frequently practiced. The overall mean of 4.20 was interpreted as always practiced. The result implies that the grantees always put high degree of importance to their personal aspect of identity. 
Relational Identity. The measure of identity orientation in terms of relational identity shows that the item "I give importance to being a good friend to those I really care about" got the highest mean rating of 4.40 which means always practiced. On the other hand, the item "Connecting on an intimate level with another person" got a mean rating of 3.66 which means frequently practiced. The overall mean of 4.10 means frequently practiced giving importance to their relational aspect of identity.

Social Identity. The measure of identity orientation of the grantees in terms of social identity shows that the strongest indicator for social identity is in terms of giving importance to social behavior, such as the way they act when meeting people, which is indicated by the mean score rating of 4.15 . The indicators "I give importance to my reputation, what others think of me"; "I give importance to the ways in which other people react to what I say and do"; "I give importance to my gestures and mannerisms, the impression I make on others"; "I give importance to my physical appearance: my height, my weight, and the shape of my body"; and "I give importance to my attractiveness to other people" were frequently practiced as indicated by the mean ratings of 4.05 , $3.98,3.89,3.72$, and 3.40 respectively. The item "I give importance to my popularity with other people" is sometimes practiced by the grantees as indicated by the mean rating of 3.26 . In relation to the aforesaid findings, it can be implied that the grantees give value to what other people say about them.

Collective Identity. The grantees frequently practiced giving importance to family background; feeling of pride in the country or being proud to be a citizen of the country; their religion; language, such as accent or dialect or a second language that they know; being a part of the many generations of their family; places where they lived or where they were raised; and their commitment on political issues or their political activities. Hence, the overall mean of 3.96 indicated that the grantees frequently practiced all the indicators for collective identity.

Table 2 presents the summary for personality adjustment in terms of identity orientation. As seen in this table, all aspects of identity were frequently practiced. Only personal identity was seen to be always practiced, which is indicated by the mean rating of 4.20. This result implies that the grantees frequently designated personal identity at first place for the description of in their own person compared to other aspects of identity. This further implies that they make decisions and choices based on personal reasons or benefits.

Table 2. Summary table for personality adjustments in terms of identity orientation

\begin{tabular}{|c|c|c|}
\hline Indicators & Mean & Interpretation \\
\hline Personal Identity & 4.20 & Always Practiced \\
\hline Physical Identity & 4.10 & Frequently Practiced \\
\hline Social Identity & 3.78 & Frequently Practiced \\
\hline Collective Identity & 3.96 & Frequently Practiced \\
\hline Grand Mean & 4.01 & Frequently Practiced \\
\hline
\end{tabular}

\section{Academic Performance of TES Grantees}

Table 3 presents the academic performance of the grantees during the school year 2019-2020. It can be gleaned from Table 3 that 26 or $9.81 \%$ are TES grantees with "Outstanding” performance, 76 or
28.68\% with "Very Satisfactory" performance, 151 or $56.98 \%$ with "Satisfactory" performance, and 12 or $4.53 \%$ have "Fairly Satisfactory" academic performance. Results show that most of the grantees are average learners.

Table 3. Frequency distribution of TES grantees in terms of academic performance

\begin{tabular}{|c|c|c|}
\hline Descriptor \& Grading Scale & $f$ & Percentage \\
\hline Outstanding (1.5 above) & 26 & 9.81 \\
\hline Very Satisfactory (2.0-1.6) & 76 & 28.68 \\
\hline Satisfactory $(2.5-2.1)$ & 151 & 56.98 \\
\hline Fairly Satisfactory (3.0-2.6) & 12 & 4.53 \\
\hline Did Not Meet Expectations (below 3.0) & 0 & 0 \\
\hline & 265 & 100 \\
\hline
\end{tabular}

Relationship between Personality Adjustments and Academic Performance of the TES Grantees

This study investigated the relationship between personality adjustments of the grantees in terms of delayed gratification and identity orientation and their academic performance. Table 4 shows that delayed gratification $(\mathrm{r}=0.029 ; \mathrm{p}=0.646)$ of the TES grantees at 0.05 level of significance showed no significant relationship with their academic performance. Thus, the null hypothesis which stated 
that there is no significant relationship between personality adjustments in terms of delayed gratification and academic performance cannot be rejected. This result is contrary to the findings of the analysis of Wulfert et al. (2012) that grade point average (GPA) and delay of gratification produced significant results. Bembenutty (2011) reiterated that individuals who are able to delay gratification are known to have higher intelligence and higher academic achievement and more socially well adapted than individuals who succumb easily to immediate impulses and temptations. The result implies that delay of gratification may not directly affect the students' academic performance on the basis of general weighted average but perhaps have impact on achieving their goals in life.

On the other hand, the identity orientation $(\mathrm{r}=$ $892 ; \mathrm{p}=0.000)$ at 0.05 level of significance had significant relationship with their academic performance. Hence, the null hypothesis which stated that there is no significant relationship between personality adjustments in terms of identity orientation and academic performance of TES grantees in Eastern Visayas is rejected. This result conforms to the conclusion drawn by Hejazi et al. (2012) that personal identity of high school students is related to academic achievement.

Table 15. Relationship between personality adjustments and academic performance

\begin{tabular}{llccc}
\hline \hline \multicolumn{1}{c}{$\begin{array}{c}\text { Independent } \\
\text { Variable }\end{array}$} & $\begin{array}{c}\text { Dependent } \\
\text { Variable }\end{array}$ & $\begin{array}{c}\text { Index of } \\
\text { Correlation }\end{array}$ & p-Value & Interpretation \\
\hline $\begin{array}{l}\text { Delayed } \\
\text { Gratification }\end{array}$ & $\begin{array}{c}\text { Academic } \\
\text { Performance }\end{array}$ & 0.029 & 0.646 & Not significant \\
$\begin{array}{l}\text { Identity } \\
\text { Orientation }\end{array}$ & 0.892 & 0.000 & Significant \\
\hline \hline
\end{tabular}

This result implies that the grantees who give importance to their identity orientation are more likely to place value on their scholastic success.

Finally, the result of the study revealed that delayed gratification is not significantly related with the academic performance of TES grantees while identity orientation affects the academic performance of TES grantees in Eastern Visayas.

\section{RECOMMENDATIONS}

The researcher recommends that personality development and values formation seminars have to be provided to boost the grantees' personality; financial management discussions have to be delivered to somehow guide the grantees in managing their finances; peer tutorial perhaps be conducted to improve the academic performance of the grantees; and to respond to the needs of the TES grantees, the SUC may conduct or intensify the Academic Enhancement Program (AEP) to develop critical experiences and skills necessary for personality development and academic success.

\section{REFERENCES}

1. Bembenutty, H. (2011). Academic delay of gratification and academic achievement.New Directions for Teaching and Learning, 126, 1124. DOI: $10.1002 / t l .444$

2. Bembenutty, H. \& Karabenick, S. (1998a). Academic delay of gratification. Learning and Individual Differences, 10(4), 329-346.

3. Cayubit, R.F., Cadacio, C.A., Chua, M.P.T., Faeldon, V.A., \& Go, W.V. (2016). Academic delay of gratification, academic achievement, and need for affiliation of selected high school students. Educational Measurement and Evaluation Review, (7) 2.

4. Cheek, J. M. \& Briggs, S. R.. (2013). Aspects of Identity Questionnaire (AIQ-IV) . Measurement Instrument Database for the Social Science. Retrieved from www.midss.ie

5. Cheek, J. M. (2002). Identity orientations and self-interpretation. In D. M. Buss \& N. Cantor (Eds.), Personality psychology: Recent trends and emerging directions (pp. 275- 285). New York: Springer-Verlag.

6. Cheek, J. M., Smith, S. \& and Tropp, S. R. (2002). Relational identity orientation: a fourth scale for the aiq. Society for Personality and Social Psychology Conference Paper . February 2002 DOI: $\quad 10.13140 / 2.1 .1643 .7763$. https://www.researchgate.net/publication/267038 939

7. Commission on Higher Education. (2020). Higher Education Facts and Figures. https://ched.gov.ph/2020-higher-education-factsand-figures/. Retrieved April 15, 2021.

8. Maranda, A., Escalona, O., Sansona, A., \& Maranda, J. (2016). Assessing the delayed gratification, identity orientation and transitional plans of ESGP-PA recipients: Implications for policies and program development. Journal of Government and Politics, 40(10), 493-515.

9. Republic Act No. 10687. 2015. Unified Student Financial Assistance System for Tertiary Education (UniFAST) Act. Quezon City: Congress of the Philippines. 
10. Republic Act No. 10931. 2017. Implementing Rules and Regulations. Universal access to quality tertiary education act. Quezon City: Congress of the Philippines.

11. Temple, S. L. (2009). Factors that influence students' desires to attend higher education. Seton Hall Univeristy, 141.

12. Wulfert, E., Block, J., Santa Ana, E., Rodriguez, M., \& Colsman, M. (2012). Delay of gratification: impulsive choices \& problem decisions in early \& late adolescence. Journal of Psychology, 70(4), 534-551. 